OPEN ACCESS

Edited by:

Giorgio Prosdocimi Gianquinto, Università degli Studi di Bologna, Italy

Reviewed by:

Barbara De Lucia,

Università degli Studi di Bari Aldo

Moro, Italy

Daniele Massa

Consiglio per la Ricerca in Agricoltura e l'Analisi dell'Economia Agraria

(CREA), Italy

*Correspondence: Debalina Saha debalina@ufl.edu

Specialty section: This article was submitted to Crop and Product Physiology,

a section of the journal Frontiers in Plant Science

Received: 11 April 2018 Accepted: 15 May 2018 Published: 30 May 2018

Citation:

Saha D, Marble SC and Pearson BJ

(2018) Allelopathic Effects of Common Landscape and Nursery Mulch Materials on Weed Control.

Front. Plant Sci. 9:733.

doi: 10.3389/fpls.2018.00733

\section{Allelopathic Effects of Common Landscape and Nursery Mulch Materials on Weed Control}

\author{
Debalina Saha*, S. Chris Marble and Brian J. Pearson
}

Department of Environmental Horticulture, Mid-Florida Research and Education Center, Institute of Food and Agricultural Sciences, University of Florida, Apopka, FL, United States

Use of organic mulch materials such as pinebark, pinestraw, or various hardwood chips for weed control is a common practice in residential and commercial landscapes. Mulch can inhibit weed seed germination and growth through light exclusion, acting as physical barrier, reducing available moisture to weed seeds within the mulch layer, and through release of allelochemicals that may inhibit germination or growth of some weed species. Previous and current research on allelopathic chemicals present in mulch have focused on cover crops and their residues with an emphasis on agronomic crops. These materials would not be suitable in a landscape setting due to rapid decomposition, lack of commercial availability, and little aesthetic appeal. Research is needed concerning identification, quantification, extraction, mechanism of release, persistence, selectivity, genetic regulation, and mode of action of potential allelochemicals present in mulch materials used for landscape purposes. More knowledge of these natural chemicals could aid practitioners and homeowners in the selection of mulch and identify potential new mulch materials that could be utilized in these industries. The purpose of this review is to summarize previous research pertaining to allelopathic compounds present in commonly used mulch materials and identify new potential mulch materials that could be utilized in the landscape sector based upon allelopathic properties. Current areas where additional research is needed are also identified.

Keywords: natural herbicides, secondary metabolites, hardwood chips, pinebark, pinestraw

\section{INTRODUCTION}

The landscape industry represents a diverse network of service companies contributing over $\$ 54$ billion in sales in the United States (Hodges et al., 2011). Weed management in non-turf areas of residential and commercial landscapes is primarily achieved through application of organic mulch materials that serve as both a weed management tool and provide aesthetic value (Marble, 2015). Materials such as pinebark, pinestraw, hardwood chips from various plant species and other, sometimes inorganic mulches (i.e., gravel or stone) are commonly used due to their low cost and/or availability, and consumer preferences (Chalker-Scott, 2007). Mulch is known to suppress weed growth through light exclusion, by creating a physical barrier, or by reducing available moisture to seeds within mulch layers (Chalker-Scott, 2007). Potential mechanisms of control that have been under-investigated for landscape mulch are allelopathic compounds. An extensive review on landscape mulch materials and their benefits has been published (Chalker-Scott, 2007). Therefore, 
the focus of this review is to synthesize previous research pertaining to allelopathic compounds present in commonly used landscape mulch materials and to discuss and/or identify new potential mulch materials that could be utilized in the landscape sector based upon allelopathic properties. We also identify current areas where additional research is needed.

\section{ALLELOCHEMICALS: MECHANISM OF CONTROL AND USE AS NATURAL HERBICIDES}

Research has shown that mulch primarily inhibits weed growth through light exclusion (Wesson and Wareing, 1967; Popay and Roberts, 1970; Fitter and Hay, 1987; Richardson et al., 2008), creation of a physical barrier (Crutchfield et al., 1986; Facelli and Pickett, 1991; Marble, 2015), and reducing available water within mulch layers (Jordan et al., 2010). While physical characteristics and depth of mulch often explain efficacy in regards to weed control (Chalker-Scott, 2007), allelopathic properties present in some mulch materials may also inhibit weed growth in certain instances.

Molisch (1937) first used the term allelopathy defined as any direct or indirect harmful effect by one plant on another through production of chemicals that are released into the environment (Rice, 1984). Allelochemicals are diverse in chemical structure and produced by plants as secondary metabolites (Paiva, 2000; Hadacek, 2002). They are released by root exudation, volatilization, and death and decay of plants, and through leaching from living or decaying residues (Rice, 1984; Anaya, 1999). Toxicity of these allelochemicals are determined by several factors including concentration, flux rate, age and metabolic state of the plant, and prevailing climate and environmental conditions (Kohli et al., 1993; Wardle et al., 1993; Weidenhamer, 1996; Gallet and Pellissier, 1997; Nilsson et al., 1998). Broadly, allelochemicals can be characterized into terpenoids and phenolics (Singh et al., 2003). Terpenoids from higher plants include volatile monoterpenes, volatile essential oils, and sesquiterpene lactones (Singh et al., 2003). Among these chemicals, volatile monoterpenes and sesquiterpene lactones show a greater degree of biological activity than others (Singh et al., 2003). Phenolic compounds are hydroxylated aromatic compounds, also referred as "tannins." Terpenoids and phenolics have been previously investigated in common mulch materials.

Allelopathic production and quantity varies within plant species, cultivar, age, plant organ, and time of the year (Argandona et al., 1981; Hanson et al., 1981; Wyman-Simpson et al., 1991; Devi et al., 1997; Burgos et al., 1999; Cambier et al., 2000). Allelochemicals produced by some species may be toxic enough to lead to death of others (Bewick et al., 1994). Rietveld et al. (1983) reported decline and death of European black alder trees [Alnus glutinosa (L.) Gaertn.] due to black walnut (Juglans nigra L.) allelopathy. This resulted from a combination of high walnut biomass causing significant release of juglone to the environment and wet soil that restricted aerobic metabolism by soil microorganisms, allowing juglone to build up to toxic levels.
Allelochemicals can also be used for weed management (Table 1) as they act as natural herbicides. Advantages of these natural products over synthetic herbicides include: (1) Natural products exhibit structural diversity and possess complex structures that could be used as an alternative for herbicide discovery; (2) Readily decompose in nature; and (3) Contain a different mode of action compared with synthetic herbicides (Duke et al., 1997, 2000; Dayan et al., 1999), providing alternative action sites for herbicides needed to control weeds in areas where few synthetic products can be used (Marble et al., 2015).

Many investigations have been completed or are ongoing evaluating use of cover crops and their residues for weed suppression. Some results are positive showing enhanced weed suppression and thereby reducing needed herbicide applications, and others with mixed results. Cover crop residue provides a weed-suppressive "mulch" effect due in part by providing a physical barrier, but also due to phytotoxins being released from decomposing residues which impacts weed control selectivity (Putnam, 1988; Weston, 1996; Burgos and Talbert, 2000; Nagabhushana et al., 2001). Rye (Secale cereale L.) can provide excellent weed control up to 2 months without affecting yield of crops such as cotton (Gossypium hirsutum L.) and soybean [Glycine $\max$ (L.) Merr.]. Rye allelopathy primarily results from presence of phytotoxins $(3 \mathrm{H})$-benzoxazolinone (or BOA) and 2,4-dihydroxy-1,4- (2H)benzoxazine-3-one (or DIBOA) (Barnes and Putnam, 1987). Research by Burgos and Talbert (2000) showed BOA or DIBOA of rye caused inhibition of germination in small to medium-seeded weed species including Palmer amaranth (Amaranthus palmeri S. Watson), large crabgrass [Digitaria sanguilanis (L.) Scop.], Indian goosegrass [Eleusine indica (L.) Gaertn.], lettuce (Lactuca sativa L.), tomato (Lycopersicon esculentum L.), and prickly fanpetals (Sida spinosa L.). Residues of corn (Zea mays L.), oats (Avena sativa L.), sorghum (Sorghum bicolor L.), and wheat (Triticum aestivum L.) and soils in which these crops are grown contain phytotoxins such as ferulic and $p$-coumaric acids. These compounds provide a weed suppressive effect when these crops are produced in no-till or reduced tillage systems and residues left on the soil surface as mulch (Guenzi and McCalla, 1966). Black mustard (Brassica nigra L.) also contains allelochemicals that can inhibit germination and seedling growth of wild oat (Avena fatua L.) (Turk and Tawaha, 2003). Isothiocyanates, an allelochemicals from mustard species, showed high activity against wheat germination and seedling growth (Bialy et al., 1990). The most active compound, 2-phenethyl ITC, completely inhibited wheat germination at 500 ppm (Bialy et al., 1990). Experiments conducted by Ferguson et al. (2003) showed that application of aqueous extracts of brassica (Brassica napus L.), sorghum, and sunflower (Helianthus annuus L.) on wheat could successfully reduce weed populations.

\section{ALLELOCHEMICALS IN COMMON LANDSCAPE MULCH MATERIALS}

Duryea et al. (1999) compared chemical, allelopathic, and decomposition properties of six common landscape mulch materials including cypress (Taxodium distichum [L.] Rich. and 
TABLE 1 | Examples of allelopathic effect of some common plants on weed suppression (partially adapted from Ferguson et al., 2003).

\begin{tabular}{|c|c|}
\hline Plant name & Allelochemicals \\
\hline $\begin{array}{l}\text { Lantana camara L. } \\
\text { (Lantana) }\end{array}$ & Phenolic compounds \\
\hline $\begin{array}{l}\text { Mangifera indica L. } \\
\text { (Mango) }\end{array}$ & $\begin{array}{l}\text { Caffeic acid, ferulic acid, coumaric acid } \\
\text { benzoic acid, hydrobenzoic and } \\
\text { cinnamic acid }\end{array}$ \\
\hline $\begin{array}{l}\text { Secale cereale L. (Rye) } \\
\text { Schedonorus } \\
\text { arundinaceus (Schreb.) } \\
\text { Dumort., nom. cons. } \\
\text { (Fescue), and Triticum } \\
\text { aestivum L. (wheat) }\end{array}$ & $\begin{array}{l}\text { Cyclic hydroxamic acid (rye), phenolic } \\
\text { acids (wheat) }\end{array}$ \\
\hline $\begin{array}{l}\text { Helianthus tuberosus L. } \\
\text { (Jerusalem artichoke) }\end{array}$ & $\begin{array}{l}\text { Salicylic acid, } p \text {-hydroxybenzaldehyde, } \\
\text { o-coumarinic acid and coumarin }\end{array}$ \\
\hline
\end{tabular}

Crotalaria juncea L. (Sunn hemp)

Cichorium intybus L. (Chicory)

Cynanchum L.

(Swallow-worts)

Tectona grandis L. f. (Teakwood)
Phenolic acids, scopoletin

Phenolic acids, benzoxazinones

Phenolic acids, simple acids

Phenolic acids, dhurrin, sorgoleone, $p$-hydroxy benzaldehyde, $p$-hydroxy benzoic acid

Allyl isothiocyanate, other water-soluble inhibitors

Fatty acids

Isoflavonoids, phenolics
Target weed/plant

Lantana roots and shoots incorporated

into soil reduced germination and

growth of milkweed vine (Morrenia

odorata Lindl.). Fifty percent of

milkweed vine seedlings died within

15 days after germination at $1 \%(\mathrm{w} / \mathrm{w})$ dried lantana root incorporated into the soil.

Dried mango leaf powder (25\% extract) inhibited sprouting of purple nutsedge

(Cyperus rotundus L.) tubers by 85-95\%.

Suppression of barnyardgrass, redroot pigweed, large crabgrass, etc.

Residual effects on weed species. Large crabgrass density is inhibited by about 37 and $66 \%$ at 30 and 55 days after incorporation of residues respectively.

Growth inhibition of smooth pigweed (Amaranthus hybridus L.) by $51 \%$ can occur as sun hemp density increases to 100 plants $\mathrm{m}^{-2}$.

Inhibition of barnyardgrass and redroot pigweed.

Invasive species in northeastern United States and southeastern Canada; inhibited several weed species such as large crabgrass and milkweed. Leaf extracts inhibited jungle rice and sedge. Leaf extracts were able to exhibit 100\% inhibition of jungle rice. Methanol extract exhibited sustained inhibitory action (GI 56-61\%) on jungle rice whereas water extract inhibited sedge germination by $25-45 \%$.

Brassica kaber (DC) Wheeler var. pinnatifida (DC) Wheeler.

Taraxacum officinale F. H. Wigg. (Common Dandelion), Cirsium arvense (L.) Scop. (Canada thistle). Lolium multiflorum Lam. (Annual ryegrass).

Redroot pigweed

Phalaris paradoxa L.

Redroot pigweed

$$
-
$$

Trianthemea portulacastrum L. (Horse purslane).

\section{Reference}

Achhireddy and Singh, 1984

Rokiek et al., 2010

Chase et al., 1991; Ferguson et al., 2003

Tesio et al., 2012

Collins et al., 2008

Nishimura et al., 2000; Ferguson et al., 2003

Ferguson et al., 2003; Douglass et al., 2011

Kole et al., 2011

Guenzi and McCalla, 1966; Rice, 1984

Shilling et al., 1985; Barnes and

Putnam, 1987; Nair et al., 1990; Mwaja et al., 1995

Guenzi and McCalla, 1966; Shilling et al., 1985

Nicollier et al., 1983; Forney and Foy, 1985; Netzley and Butler, 1986; Weston et al., 1989; Einhellig et al., 1993

Muller, 1969; Bell and Muller, 1973

Tsuzuki et al., 1987

Rice, 1984

Narwal et al., 1998; Narwal, 2000

Pennisetum typhoides 
T. distichum var. nutans [Ait.] Sweet), eucalyptus (Eucalyptus grandis W. Hill ex Maiden), pinebark \{splash pine (Pinus elliottii [Engelm.]) and loblolly pine (P. taeda [L.])\}, pine needle (Pinus elliottii [Engelm.]), melaleuca (Melaleuca quinquenervia [Cav.] S. T. Blake), and a utility-trimming mulch (GRU) composed of multiple species [oaks, Quercus laurifolia Michx. and Q. rubra (L.), Q. virginiana Mill., and cherry (Prunus serotina Ehrh.)], with a small amount of southern redcedar [Juniperus virginiana L. var. silicicola (Small) Silba] and southern pines (Pinus spp.). Bioassays were conducted by extracting water-soluble chemicals from the mulches followed by application to germinating lettuce seeds and germinants for each mulch extract were recorded. Results showed hydroxylated aromatic compounds were highest in GRU and lowest in melaleuca, pinebark, and pinestraw, but all showed levels of significant activity in bioassay (Duryea et al., 1999). The authors hypothesized allelopathic properties of these mulches could potentially reduce germination of landscape weed species, but were not evaluated.

Rathinasabapathi et al. (2005) demonstrated that water eluates from wood chips of southern redcedar, red maple (Acer rubrum L.), swamp chestnut oak (Quercus michauxii Nutt.), neem (Azadirachta indica A. Juss.), and magnolia (Magnolia grandiflora L.) inhibited radicle growth in germinating lettuce. It was also observed that eluates from wood chip mulch of neem, swamp chestnut oak, and red cedar inhibited the hypocotyl growth. Hardwood chips from eucalyptus and cypress, both common in southeast United States, contain more phenolic compounds (tannins) than pinebark and pinestraw (Duryea et al., 1999) and may inhibit germination of weed seeds and seedling growth. Some of the phenolic compounds identified in eucalyptus hardwood are quinic acid, gallic acid, protocatechuic acid, catechin, and chlorogenic acid (Santos et al., 2013).

Maimoona et al. (2011) demonstrated that bark of chir pine (Pinus roxburghii Sarg.) and Bhutan pine (Pinus wallichiana A. B. Jacks) contained catechin and gallocatechin derivative, quercetin, kaempferol, secoisolariresinol, 3, 4-dihydroxybenzoic acid, and rhamnetin. Previous studies have showed that allelopathy in conifers is due to the presence of phenolic compounds. The above-mentioned phenolic compounds present in the pinebark may be responsible for allelopathy. Terpenoids, such as $\beta$-pinene, myrcene, camphor, and cineole, a group of naturally occurring chemicals, have allelopathic effects as toxic, inhibitory or deterrent compounds (Langenheim, 1994). Harman-Ware et al. (2016) reported presence of monoterpenes, $\alpha$ - and $\beta$-pinene, camphene, and $\delta$-carene in the terpenoids extract of loblolly pine saplings and pine lighter wood. The $\beta$-pinene and camphene are two important potential allelopathic compounds that may be present in pinebark mulch materials and responsible for inhibition of weed seed germination and growth. Further studies are needed to identify the specific allelochemicals present in pinebark mulch, as not much information is available.

Research has been conducted to identify allelochemicals present in pines, and various phenolic acids and their related compounds were isolated from pinebark, needles, and even from soils in pine communities (Lee and Monsi, 1963; ChuCho, 1978; Lodhi and Killingbeck, 1982; Kil and Yim, 1983; Son et al., 1996; Node et al., 2003). Kato-Noguchi et al. (2009) identified $9 \alpha, 13 \beta$-epidioxyabeit-8 (14)en-18-oic acid in the extracts of red pine (Pinus densiflora) needles that inhibited root growth of cress (Lepidium sativum L.), lettuce, alfalfa (Medicago sativa L.), ryegrass [Lolium multiflorum (Lam) Husnot], timothygrass (Phleum pratense L.), large crabgrass and barnyardgrass [Echinochloa crus-galli (L.) Beauv.] by 9 to $18 \%$ and shoot growth of these species by 20 to $65 \%$. It was also observed that with the increase in the extract concentration, there was increased inhibition, suggesting allelopathic potential of red pine needles.

\section{POTENTIAL MULCH SPECIES}

Woody plant vegetation management is needed from municipalities and utility companies in order to maintain highway right-of-way visibility and safety, and provide access to utility lines and transformers. This routine maintenance results in large quantities of woody plant debris that is often ground into "utility mulch" and sold for disposal and to recoup costs (Duryea, 2000). Utility mulch varies widely in composition, but often contains a mixture of hardwood species and in many areas such as Florida, a high proportion could contain invasive tree species due to their prevalence. Many invasive plants have been shown to contain high amounts of allelopathic compounds as a defense mechanism, increasing their chance of survival and proliferation (Orr et al., 2005). Several of these species could serve as potential mulch materials due to both their allelopathic properties and frequency in which they are removed following management activities (Table 2).

Rice (1984) suggested that certain species of melaleuca may have allelopathic properties similar to eucalyptus as both belong to Myrtaceae. Yatagai et al. (1998) studied germination and growth-inhibition activity of five Melaleuca species including, M. saligna Schau., M. acacoides F. Muell., M. dealbata S. T. Blake., M. symphyocarpa F. Muell., M. argentea W. V. Fitzg, M. bracteata F. Muell. on radish (Raphanus sativus L.) seeds and found that $0.1 \%$ of $M$. bracteata leaf oil was able to inhibit the growth and germination of radish seed completely whereas leaf oil from the other five species inhibited growth by 30 to $85 \%$. However, when weed species were tested results were not as promising. Essential oils of M. armillaris (Sd. Ex Gaertn.) Sm., M. styphelioides Sm., and $M$. acuminata F. Muell. reduced radical elongation of radish, garden cress (Lepidium sativum L.), charlock mustard (Sinapis arvensis L.), durum wheat (Triticum durum L.), and canary grass (Phalaris canariensis L.) but did not reduce germination (Amri et al., 2012).

Chinese tallow [Triadica sebifera (L.) Small] is an exotic tree that has become highly invasive (Jubinsky and Anderson, 1996). Tallow trees are reported to have allelopathic properties in their leaves, which can alter soil chemistry and can affect native vegetation, negatively (Flack and Furlow, 1996). Tallow has been suspected of allelopathic interference on loblolly pine regeneration as understory vegetation in a multilayered plant community (Gresham, 1986). Previous studies have detected potential allelochemicals such as tannins in tallow leaves and bark (Cameron and LaPoint, 1978; Yang and Kinghorn, 1985) and its leaves are toxic to herbivores (Russell et al., 1969). 
TABLE 2 | Allelopathic properties of common and potential mulch species.

\begin{tabular}{|c|c|c|c|}
\hline Plant name & Allelochemicals & Target weed/plant & Reference \\
\hline $\begin{array}{l}\text { Ailanthus altissima (Mill.) (Tree of } \\
\text { heaven) }\end{array}$ & $\begin{array}{l}\text { Ailanthone, isolated from this plant has } \\
\text { been reported to possess non-selective } \\
\text { post-emergence herbicidal activity } \\
\text { similar to glyphosate and paraquat }\end{array}$ & $\begin{array}{l}\text { Redroot pigweed, garden cress, foxtail } \\
\text { and barnyard grass }\end{array}$ & Heisey, 1990 \\
\hline $\begin{array}{l}\text { Melaleuca armillaris (Sd. Ex Gaertn.) } \\
\text { (Melaleuca) }\end{array}$ & $\begin{array}{l}\text { 1,8-Cineole and terpinen-4-ol essential } \\
\text { oils }\end{array}$ & Radish, garden cress, and canary grass & Farag et al., 2004; Amri et al., 2012 \\
\hline M. styphelioides (Sm.) (Melaleuca) & $\begin{array}{l}\text { Caryophyllene oxide and spathulenol } \\
\text { essential oils }\end{array}$ & Radish, garden cress, and canary grass & Farag et al., 2004; Amri et al., 2012 \\
\hline $\begin{array}{l}\text { Triadica sebifera [(L.) Small] (Chinese } \\
\text { tallow) }\end{array}$ & Tannins, phenols, and alkaloids & Loblolly pine & Gresham, 1986 \\
\hline $\begin{array}{l}\text { Schinus terebinthifolia (Raddi) (Brazilian } \\
\text { pepper) }\end{array}$ & Sesquiterpenes & Lettuce and cucumber & Barbosa et al., 2007 \\
\hline Juglans nigra (L.) (Black walnut) & Juglone & $\begin{array}{l}\text { Crimson clover, crown vetch, and hairy } \\
\text { vetch }\end{array}$ & Rietveld, 1983 \\
\hline Pinus halepensis (L.) (Aleppo pine) & $\begin{array}{l}\text { Phenolic compounds present in pine } \\
\text { needle/pinestraw }\end{array}$ & $\begin{array}{l}\text { Inhibited growth of tall fescue (Festuca } \\
\text { arundinacea Schreb.) and } \\
\text { bermudagrass (Cynodon dactylon [L.] } \\
\text { Pers.) }\end{array}$ & Nektarios et al., 2005 \\
\hline $\begin{array}{l}\text { Eucalyptus grandis (W. Hill ex Maiden) } \\
\text { (Eucalyptus) }\end{array}$ & $\begin{array}{l}\text { Phenolic compounds (tannins) present } \\
\text { in hardwood chips }\end{array}$ & Inhibited germination of lettuce seeds & Duryea et al., 1999 \\
\hline Pinus elliottii (Engelm.) (Splash pine) & $\begin{array}{l}\text { Hydroxylated aromatic compounds } \\
\text { present in pinebark }\end{array}$ & Inhibited germination of lettuce seeds & Duryea et al., 1999 \\
\hline $\begin{array}{l}\text { Quercus laurifolia (Michx.), Q. rubra (L.), } \\
\text { Q. virginiana (Mill) (Oaks) } \\
\text { (Utility-trimming mulch) }\end{array}$ & $\begin{array}{l}\text { Presence of high amount of } \\
\text { hydroxylated aromatic compounds }\end{array}$ & Inhibited germination of lettuce seeds & Duryea et al., 1999 \\
\hline $\begin{array}{l}\text { Prunus serotina (Ehrh.) (Cherry) } \\
\text { (Utility-trimming mulch) }\end{array}$ & $\begin{array}{l}\text { Presence of high amount of } \\
\text { hydroxylated aromatic compounds }\end{array}$ & Inhibited germination of lettuce seeds & Duryea et al., 1999 \\
\hline
\end{tabular}

Chemicals including 6, 7, 8-trimethoxycoumarin and scopoletin, both chemicals belonging to the coumarin group and produced for plant defensive purposes, have been obtained from Chinese tallow bark a root extracts (Yang and Kinghorn, 1985). However, more research is needed to determine what activity, if any, these extracts may have on common weed species.

Brazilian pepper (Schinus terebinthifolia Raddi) is another exotic invasive plant in Florida (Morgan and Overholt, 2004). Donnelly et al. (2008) reported reductions in growth and biomass in black mangrove [Avicennia germinans (L.) L.] when exposed to the highest density of intact Brazilian pepper fruits growing in 30 ppt (parts salt per 1000 parts seawater) saltwater. They also observed that crushed fruits significantly decreased growth and leaf production of red mangrove (Rhizophora mangle L.). The oil content of both leaves and unripe fruit of Brazilian pepper contain sesquiterpenes (from 78.0 to 90.4\%) (Barbosa et al., 2007). Sesquiterpenes found in Brazilian pepper have been shown to inhibit radicle growth of lettuce (88.6-92.4\%) and cucumber (Cucumis sativus L.) (50.5-84.5\%) at $10,000 \mu \mathrm{g} \mathrm{mL}^{-1}$ concentration (Barbosa et al., 2007).

Tree of heaven [Ailanthus altissima (Mill.) Swingle] is another potential plant species for landscape mulch production. The extracts from the fresh leaves of tree of heaven showed germination/growth inhibitory effect against alfalfa in laboratory bioassays (Tsao et al., 2002). De Feo et al. (2003) reported that aqueous root extract of tree of heaven exhibits allelopathic activity against radish, garden cress, and common purslane (Portulaca oleracea L.) seeds, the latter two species being important weed species. Heisey (1990) tested the allelopathic effect of root bark extract of tree of heaven on seven herbaceous plant species including redroot pigweed (Amaranthus retroflexus L.), garden cress, velvetleaf (Abutilon theophrasti Medik.), foxtail [Setaria pumila (Poir.) Roem. and Schult.], barnyard grass, garden pea (Pisum sativum cv. 'Sugar Snap'), and corn (Zea mays L.) by applying to seeds pre- and post-emergence. Root bark extract showed a strong herbicidal activity when applied to greenhouse soil both pre- and post-emergence to all seven species. Postemergence application resulted in complete mortality of all species with the exception of velvetleaf.

Black walnut trees are native to the United States and often found growing on landscape sites with other shade trees. They produce a non-toxic, colorless chemical known as hydrojuglone present in leaves, stems, fruit hulls, inner bark and roots. When hydrojuglone is exposed to soil compounds or air, it is oxidized into allelochemicals juglone, which is extremely toxic (Appleton et al., 2000). Rietveld (1983) determined juglone sensitivity of 16 species including \{crimson clover (Trifolium incarnatum L.), crown vetch (Coronilla varia L.), hairy vetch (Vicia villosa Roth.), Korean lespedeza (Lespedeza stipulacea Maxim.), sericea lespedeza [L. cuneata (Dumont) G. Don], ginnala maple (Acer ginnala Maxim.), Siberian peashrub (Caragana arbor-escens Lam.), Russian olive (Elaegnus angustifolia L.), autumn olive (E. umbellata Thunb.), amur honeysuckle (Lonicera maackii Maxim.), white oak (Quercus alba L.), white ash (Fraxinus americana L.), yellow poplar (Liriodendron tulipifera L.), European black alder, eastern white pine (Pinus strobus L.), 
and Scotch pine $(P$. sylvestris L.) $\}$. He reported that amur honeysuckle, sericea lespedeza, crimson clover, European black alder, and autumn olive were most sensitive to juglone in terms of seedling shoot elongation and dry weight accumulation at concentration as low as $10^{-6} \mathrm{M}$. Whereas, all other species were wilted and eventually died by $10^{-3} \mathrm{M}$ juglone, and most of them were chlorotic and extremely stunted at $10^{-4} \mathrm{M}$ juglone. Juglone and decomposed walnut leaf sap can also negatively affect root and stem development of muskmelon (Cucumis melo L.) and cucumber seedlings and the negative effect deceases as dilution ratios of decomposed leaf juice increases (Terzi, 2008). While black walnut is a high value species for timber (Campbell and Dawson, 1989), residual materials that are lost during harvesting procedures could potentially be used in certain landscape situations.

\section{KNOWLEDGE GAPS AND FUTURE PROSPECTS FOR RESEARCH}

Although research has focused on allelopathic properties of various agronomic crop residues and cover crops, and their effect on weed suppression or potential as natural herbicides/herbicide templates (Weston, 2005), these materials would not be suitable in landscapes due to rapid decomposition, availability, and appearance (Marble, 2015). There remains a significant knowledge gap concerning identification and quantification of potential allelochemicals present in the common landscape mulch materials. In addition to characterizing allelopathic properties of current and potential mulch materials (Table 2),

\section{REFERENCES}

Achakzai, A. K. H., Achakzai, P., Masood, A., Kayani, S. A., and Tareen, R. B. (2009). Response of plant parts and age on the distribution of secondary metabolites on plants found in Quetta. Pak. J. Bot. 41, 2129-2135.

Achhireddy, N. R., and Singh, M. (1984). Allelopathic effects of lantana (Lantana camara) on milkweedvine (Morrenia odorata). Weed Sci. 32, 757-761. doi: 10.1017/S0043174500059944

Amri, I., Mancini, E., Martino, L. D., Marandino, A., Lamia, H., Mohsen, H., et al. (2012). Chemical composition and biological activities of the essential oils from three Melaleuca species grown in Tunisia. Int. J. Mol. Sci. 13, 16580-16591. doi: 10.3390/ijms131216580

Anaya, A. L. (1999). Allelopathy as a tool in the management of biotic resource in agroecosystems. Crit. Rev. Plant Sci. 18, 697-739. doi: 10.1080/ 07352689991309450

Appleton, B., Berrier, R., Harris, R., Alleman, D., et al. (2000). The Walnut Tree: Allelopathic Effects and Tolerant Plants. Virginia Cooperative Extension, Virginia Tech. Available at: https://vtechworks.lib.vt.edu/bitstream/handle/ 10919/51323/VCE430_021_2000.pdf?sequence=1 [accessed April 6, 2018].

Argandona, V. H., Niemeyer, H. M., and Corcuera, L. J. (1981). Effects of content and distribution of hydroxamic acids in wheat on infestation by the aphid Schizaphis graminum. Phytochemistry 20, 673-676. doi: 10.1016/0031-9422(81) 85154-0

Barbosa, L. C. A., Demuner, A. J., Clemente, A. D., de Paula, V. F., and Ismail, F. M. D. (2007). Seasonal variation in the composition of volatile oils from Schinus terebinthifolius raddi. Quim. Nova 30, 1959-1967. doi: 10.1590/S010040422007000800030

Barnes, J. P., and Putnam, A. R. (1987). Role of benzoxazinones in allelopathy by rye (Secale cereal L.). J. Chem. Ecol. 13, 889-905. doi: 10.1007/BF01020168 further investigation of the mechanism of action of allelochemicals is also deserved (Weston, 2005). Another aspect to consider is the extraction process of the newly identified allelochemicals from landscape mulches and if their persistence in the environment in sufficient concentration to affect weed species (Ferguson et al., 2003). From a commercial perspective, further work is also needed to identify how aging and handling these materials after harvest impacts allelochemical composition, as age has been shown to have a significant effect (Achakzai et al., 2009). Mulch availability typically varies by region and what materials are available locally (Marble, 2015). A better understanding of potential allelopathic effects of these mulch materials could be used by mulch manufacturers for promotion and to aid the horticulture industry in selecting mulch for different applications. Due to a high degree of variability in both allelopathic potential and weed species response reported here, it is important that researchers identify key characteristics of mulch materials used including plant species, age, plant parts used, and harvesting and handling procedures prior to experimentation. Identifying activity of these compounds on economically important weed species, in lieu of bioassay species such as lettuce or radish, would also be beneficial from a weed management perspective.

\section{AUTHOR CONTRIBUTIONS}

DS and SM reviewed and wrote the manuscript. DS, SM, and BP gathered information from various sources.

Bell, D. T., and Muller, C. H. (1973). Dominance of California annual grasslands by Brassica nigra. Am. Midl. Nat. 90, 277-299. doi: 10.2307/2424453

Bewick, T. A., Shilling, D. G., Dusky, J. A., and Williams, D. (1994). Effects of celery (Apium graveolens) root residues on growth of various crops and weeds. Weed Technol. 8, 625-629. doi: 10.1017/S0890037X00039804

Bialy, Z., Oleszek, W., Lewis, J., and Fenwick, G. R. (1990). Allelopathic potential of glucosinolates (mustard oil glycosides) and their degradation products against wheat. Plant Soil 129, 277-281. doi: 10.1007/BF00032423

Burgos, N. R., and Talbert, R. E. (2000). Differential activity of allelochemicals from Secale cereale in seedling bioassays. Weed Sci. 48, 302-310. doi: 10.1614/00431745(2000)048[0302:DAOAFS]2.0.CO;2

Burgos, N. R., Talbert, R. E., and Mattice, J. D. (1999). Cultivar and age differences in the production of allelochemicals by Secale cereale. Weed Sci. 47, 481-485.

Cambier, V., Hance, T., and Hoffman, E. (2000). Variation of DIMBOA and related compounds content in relation to the age and plant organ in maize. Phytochemistry 53, 223-229. doi: 10.1016/S0031-9422(99)00498-7

Cameron, G. N., and LaPoint, T. W. (1978). Effects of tannins on the decomposition of Chinese tallow leaves by terrestrial and aquatic invertebrates. Oecologia 32, 349-366. doi: 10.1007/BF00345113

Campbell, G. E., and Dawson, J. O. (1989). Growth, yield, and value projections for black walnut interplantings with black alder and autumn olive. North J. Appl. For. 6, 129-132. doi: 10.1093/njaf/6.3.129

Chalker-Scott, L. (2007). Impact of mulches on landscape plants and the environment- a review. J. Environ. Hortic. 25, 239-249.

Chase, W. R., Nair, M. G., and Putnam, A. R. (1991). 2,2'-Oxo-1,1'-Azobenzene: selective toxicity of rye (Secale cereal L.) allelochemicals to weed and crop species:II. J. Chem. Ecol. 17, 9-19. doi: 10.1007/BF00994418

Chu-Cho, M. (1978). Allelopathy of pinecone in Japanese red pine tree (Pinus densiflora Sieb. et Zucc.). Ann. Appl. Biol. 90, 407-416. doi: 10.1046/j.1445-6664. 2003.00092.x 
Collins, A. S., Chase, C. A., Stall, W. M., and Hutchinson, C. M. (2008). Optimum densities of three leguminous cover crops for suppression of smooth pigweed (Amaranthus hybridus). Weed Sci. 56, 753-761. doi: 10.1614/WS-07101.1

Crutchfield, D. A., Wicks, G. A., and Burnside, O. C. (1986). Effect of winter wheat (Triticum aestivum) straw mulch level on weed control. Weed Sci. 34, 110-114.

Dayan, F., Romagni, J., Tellez, M., Rimando, A., and Duke, S. (1999). Managing weeds with natural products. Pestic. Outlook 10, 185-188.

De Feo, V., De Martino, L., Quaranta, E., and Pizza, C. (2003). Isolation of phytotoxic compounds from Tree-of-heaven (Ailanthus altissima Swingle). J. Agric. Food Chem. 51, 1177-1180. doi: 10.1021/jf020686+

Devi, S. R., Pellissier, F., and Prasad, M. N. V. (1997). "Allelochemicals," in Plant Ecophysiology, ed. M. N. V. Prasad (New York, NY: John Wiley \& Sons), 253-303.

Donnelly, M. J., Green, D. M., and Walters, L. J. (2008). Allelopathic effects of fruits of the Brazilian pepper Schinus terebinthifolius on growth, leaf production and biomass of seedlings of the red mangrove Rhizophora mangle and the black mangrove Avicennia germinans. J. Exp. Mar. Biol. Ecol. 357, 149-156. doi: 10.1016/j.jembe.2008.01.009

Douglass, C. H., Weston, L. A., and Wolfe, D. (2011). Phytotoxicity and potential allelopathy in pale (Cynanchum rossicum) and black swallowwort (C. nigrum). Invasive Plant Sci. Manage. 4, 133-141. doi: 10.1614/IPSM-D-10-00 021.1

Duke, S. O., Dayan, F. E., Hernandez, A., Duke, M. V., and Abbas, H. K. (1997). "Natural products as leads for new herbicide modes of action," in Proceedings of the 1997 Brighton Crop Protection Conference-Weeds, Vol. 2, ed. K. E. Pallett (Farnham: British Crop Production Council), 579-586.

Duke, S. O., Romagni, J. G., and Dayan, F. E. (2000). Natural products as sources for new mechanisms of herbicidal action. Crop Prot. 19, 583-589. doi: 10.1016/ S0261-2194(00)00076-4

Duryea, M. L. (2000). Landscape Mulches: What are the Choices in Florida? Gainesville, FL: University of Florida.

Duryea, M. L., English, R. J., and Hermansen, L. A. (1999). A comparison of landscape mulches: chemical, allelopathic, and decomposition properties. J. Arboric. 25, 88-96.

Einhellig, F. A., Rasmussen, J. A., Hejl, A. M., and Souza, I. F. (1993). Effects of root exudate sorgoleone on photosynthesis. J. Chem. Ecol. 19, 369-375. doi: 10.1007/BF00993702

Facelli, J. M., and Pickett, S. T. A. (1991). Plant litter: its dynamics and effects on plant community structure. Bot. Rev. 57, 1-32. doi: 10.1007/BF02858763

Farag, R. S., Shalaby, A. S., El-Baroty, G. A., Ibrahim, N. A., Ali, M. A., and Hassan, E. M. (2004). Chemical and biological evaluation of the essential oils of different Melaleuca species. Phytother. Res. 18, 30-35. doi: 10.1002/ptr.1348

Ferguson, J. F., Rathinasabapathi, B., and Chase, C. A. (2003). Allelopathy: How Plants Suppress Other Plants. Gainesville, FL: University of Florida.

Fitter, A. H., and Hay, R. K. M. (1987). Environmental Physiology of Plants, 2nd Edn. London: Academic Press.

Flack, S., and Furlow, E. (1996). America's least wanted “purple plague," "green cancer" and 10 other ruthless environmental thugs. Nat. Conserv. Mag. 46, 1-31.

Forney, D. R., and Foy, C. L. (1985). Phytotoxicity of products from rhizospheres of a sorghum-sudangrass hybrid (S. bicolor X S. sudanense). Weed Sci. 33, 597-604. doi: 10.1017/S0043174500082941

Gallet, C., and Pellissier, F. (1997). Phenolic compounds in natural solutions of coniferous forests. J. Chem. Ecol. 23, 2401-2412. doi: 10.1023/B:JOEC. 0000006682.50061 .83

Gresham, C. A. (1986). "Potential allelopathic interactions of Sapium sebiferum on loblolly pine germination and seedling growth," in Proceedings of the Fourth Biennial Southern Silvicultural Research Conference United States Forest Service General Technical Report SE-42, Atlanta, GA.

Guenzi, W. D., and McCalla, T. M. (1966). Phenolic acids in oats, wheat, sorghum and corn residues and their phytotoxicity. Aron. J. 58, 303-304. doi: 10.2134/ agronj1966.00021962005800030017x

Hadacek, F. (2002). Secondary metabolites as plant traits: current assessment and future perspectives. Crit. Rev. Plant Sci. 21, 273-322. doi: 10.1080/0735260291044269

Hanson, A. D., Traynor, P. L., Ditz, K. M., and Reicosky, D. A. (1981). Gramine in barley forage-effects of genotype and environment. Crop Sci. 21, 726-730. doi: 10.2135/cropsci1981.0011183X002100050024x
Harman-Ware, A. E., Sykes, R., Peter, G. F., and Davis, M. (2016). Determination of terpenoids content in pine by organic solvent extraction and fast-GC analysis. Front. Energy Res. 4:2. doi: 10.3389/fenrg.2016.00002

Heisey, R. M. (1990). Allelopathic and herbicidal effects of extracts from tree of heaven (Ailanthus altissima). Am. J. Bot. 77, 662-670. doi: 10.2307/244 4812

Hodges, A. W., Hall, C. R., and Palma, M. A. (2011). Economic contributions of the green industry in the United States in 2007-08. Horttechnology 21, 628-638.

Jordan, A., Zavala, L. M., and Gil, J. (2010). Effects of mulching on soil physical properties and runoff under semi-arid conditions in southern Spain. Catena 81, 77-85. doi: 10.1016/j.catena.2010.01.007

Jubinsky, G., and Anderson, L. C. (1996). The invasive potential of Chinese tallow-tree (Sapium sebiferum Roxb.) in the southeast. Castanea 61, 226-231.

Kato-Noguchi, H., Fushimi, Y., and Shigemori, H. (2009). An Allelopathic substance in red pine needles (Pinus densiflora). J. Plant Physiol. 166, 442-446. doi: 10.1016/j.jplph.2008.06.012

Kil, B. S., and Yim, Y. J. (1983). Allelopathic effects of Pinus densiflora on undergrowth of red pine forest. J. Chem. Ecol. 8, 1135-1151. doi: 10.1007/ BF00982217

Kohli, R. K., Rani, D., and Verma, R. C. (1993). A mathematical model to predict tissue response to parthenin-an allelochemic. Biol. Plant. 35, 567-576. doi: $10.1007 / \mathrm{BF} 02928034$

Kole, R. K., RoyKarmakar, P., Poi, R., and Mazumdar, D. (2011). Allelopathic inhibition of teak leaf extract: a potential pre-emergent herbicide. J. Crop Weed 7, 101-109.

Langenheim, J. H. (1994). Higher plant terpenoids: a phytocentric overview of their ecological roles. J. Chem. Ecol. 20, 1223-1280. doi: 10.1007/BF02059809

Lee, I. K., and Monsi, M. (1963). Ecological studies on Pinus densiflora forest 1. Effects of plant substances on the floristic composition of the undergrowth. Bot. Mag. 76, 400-413. doi: 10.15281/jplantres1887.76.400

Lodhi, M. A. K., and Killingbeck, K. T. (1982). Effects of pine-produced chemicals on selected understory species in a Pinus ponderosa community. J. Chem. Ecol. 8, 275-283. doi: 10.1007/BF00984023

Maimoona, A., Naeem, I., Saddiqe, Z., Ali, N., Ahmed, G., and Shah, I. (2011). Analysis of total flavonoids and phenolics in different fractions of bark and needle extracts of Pinus roxburghii and Pinus wallichiana. J. Med. Plants Res. 5, 2724-2728.

Marble, S. C. (2015). Herbicide and mulch interactions: a review of the literature and implications for the landscape maintenance industry. Weed Technol. 29, 341-349. doi: 10.1614/WT-D-14-00165.1

Marble, S. C., Koeser, A. K., and Hasing, G. (2015). A review of weed control practices in landscape planting beds: part II- chemical weed control methods. Hortic. Sci. 50, 857-862.

Molisch, H. (1937). The effects of plants on each other. Fischer Jena 31, 12-16.

Morgan, E. C., and Overholt, W. A. (2004). Potential allelopathic effects of Brazilian pepper (Schinus terebinthifolius Raddi, Anacardiaceae) aqueous extract on germination and growth of selected Florida native plants. J. Torrey Bot. Soc. 132, 11-15. doi: 10.3159/1095-5674(2005)132[11:PAEOBP]2.0.CO;2

Muller, C. H. (1969). Allelopathy as a factor in ecological process. Vegetatio 18, 348-357. doi: 10.1007/BF00332847

Mwaja, V., Masiunas, J. B., and Weston, L. A. (1995). The effect of fertility on biomass, phytotoxicity and allelochemicals content of cereal rye. J. Chem. Ecol. 21, 81-96. doi: 10.1007/BF02033664

Nagabhushana, G. G., Worsham, A. D., and Yenish, J. P. (2001). Allelopathic cover crops to reduce herbicide use in sustainable agricultural systems. Allelopathy $\mathrm{J}$. 8, 133-146.

Nair, M., Whitenack, C. J., and Putnam, A. R. (1990). 2,2'-Oxo-1,1'-azobenzene: a microbially-transformed allelochemicals from 2,3-benzoxazolinone. J. Chem. Ecol. 16, 353-364. doi: 10.1007/BF01021770

Narwal, S. S. (2000). Weed management in rice: wheat rotation by allelopathy. Crit. Rev. Plant Sci. 19, 249-266. doi: 10.1080/07352680091139222

Narwal, S. S., Sarmah, M. K., and Tamak, J. C. (1998). "Allelopathic strategies for wheat management in the rice-wheat rotation in northwestern India," in Proceedings of the Workshop on Allelopathy in rice, ed. M. Olofsdotter (Manila: International Rice Research Institute), 117-132.

Nektarios, P. A., Economou, G., and Avgoulas, C. (2005). Allelopathic effects of Pinus halepensis needles on turfgrasses and biosensor plants. Hortic. Sci. 40, 246-250. 
Netzley, D. H., and Butler, L. G. (1986). Roots of sorghum exude hydrophobic droplets containing biologically active components. Crop Sci. 26, 775-780. doi: $10.2135 /$ cropsci1986.0011183X002600040031x

Nicollier, J. F., Pope, D. F., and Thompson, A. C. (1983). Biological activity of dhurrin and other compounds from johnsongrass (Sorghum halepense). J. Agric. Food Chem. 31, 744-748. doi: 10.1021/jf00118a016

Nilsson, M. C., Gallet, C., and Wallstedt, A. (1998). Temporal variability of phenolics and batatastin III in Empetrum hermaphroditum leaves over an eight-year period: interpretations of ecological functions. Oikos 81, 6-16. doi: $10.2307 / 3546462$

Nishimura, H., Kondo, Y., Kagasaka, T., and Satoh, A. (2000). Allelochemicals in Chicory and utilization in processed foods. J. Chem. Ecol. 26, 2233-2241. doi: 10.1023/A:1005584819674

Node, M., Tomita-Yokotani, K., Suzuki, T., Kosemura, S., Hirata, H., Hirata, K., et al. (2003). Allelopathy of pinecone in Japanese red pine tree (Pinus densiflora Sieb. et Zucc.). Weed Biol. Manage. 3, 111-116. doi: 10.1046/j.1445-6664.2003. 00092.x

Orr, S. P., Rudgers, J. A., and Clay, K. (2005). Invasive plants can inhibit native tree seedlings: testing potential allelopathic mechanisms. Plant Ecol. 181, 153-165. doi: 10.1007/s11258-005-5698-6

Paiva, N. L. (2000). An introduction to the biosynthesis of the chemicals used in plant-microbe communication. J. Plant Growth Regul. 19, 131-143.

Popay, A. I., and Roberts, E. H. (1970). Ecology of Capsella bursa-pastoris (L.) Medik and Senecio vulgaris L. relation to germination behaviour. J. Ecol. 58, 123-139. doi: $10.2307 / 2258172$

Putnam, A. R. (1988). Allelochemicals from plants as herbicides. Weed Technol. 2, 510-518. doi: 10.1017/S0890037X00032371

Rathinasabapathi, B., Furguson, J., and Gal, M. (2005). Evaluation of allelopathic potential of wood chips for weed suppression in horticultural production systems. Hortic. Sci. 40, 711-713.

Rice, E. L. (1984). Allelopathy, 2nd Edn. Orlando, FL: Academic press.

Richardson, B., Gilliam, C. H., Fain, G. B., and Wehtje, G. R. (2008). Container nursery weed control with pine bark mini-nuggets. J. Environ. Hortic. 26, $144-148$.

Rietveld, W. J. (1983). Allelopathic effects of juglone on germination and growth of several herbaceous and woody species. J. Chem. Ecol. 9, 295-308. doi: 10.1007/ BF00988047

Rietveld, W. J., Schlesinger, R. C., and Kessler, K. J. (1983). Allelopathic effects of black walnut on European black alder coplanted as a nurse species. J. Chem. Ecol. 9, 1119-1133. doi: 10.1007/BF00982216

Rokiek, E., Kowthar, G., Rafat, R., Masry, E., Nadia, M. K., and Salah, A. A. (2010). The allelopathic effect of mango leaves on the growth and propagative capacity of purple nutsedge (Cyperus rotundus L.). J. Am. Sci. 6, 151-159.

Russell, L. H., Schwartz, W. L., and Dollahite, J. W. (1969). Toxicity of Chinese tallow tree (Sapium sebiferum). Am. J. Vet. Res. 30, 1233-1238.

Santos, S. A., Vilela, C., Freire, C. S., Neto, C. P., and Silvestre, A. J. (2013). Ultra-high performance liquid chromatography coupled to mass spectrometry applied to the identification of valuable phenolic compounds from Eucalyptus wood. J. Chromatogr. B 938, 65-74. doi: 10.1016/j.jchromb.2013.08.034

Shilling, D. G., Liebl, R. A., and Worsham, A. D. (1985). "Rye and wheat mulch: the suppression of certain broadleaf weeds and the isolation and identification of phytotoxins," in The Chemistry of Allelopathy: Biochemical Interactions Among Plants, ed. A. C. Thompson (Washington, DC: American Chemical Society), 243-271. doi: 10.1021/bk-1985-0268.ch017

Singh, H. P., Batish, D. R., and Kohli, R. K. (2003). Allelopathic interactions and allelochemicals: new possibilities for sustainable weed management. Crit. Rev. Plant Sci. 22, 239-311. doi: 10.1080/713610858
Son, D. S., Eon, T. J., Seo, J. D., and Lee, S. R. (1996). A study on resistant substance to pine needle gall midge among phenolic compounds in pine needles. J. Korean Forry Soc. 85, 372-380.

Terzi, I. (2008). Allelopathic effects of juglone and decomposed walnut leaf juice on muskmelon and cucumber seed germination and seedling growth. Afr. J. Biotechnol. 7, 1870-1874.

Tesio, F., Vidotto, F., and Ferrero, A. (2012). Allelopathic persistence of Helianthus tuberosus L. residues in the soil. Sci. Hortic. 135, 98-105. doi: 10.1016/j.scienta. 2011.12.008

Tsao, R., Romanchuk, F. E., Peterson, C. J., and Coats, J. R. (2002). Plant growth regulatory effect and insecticidal activity of the extracts of the Tree of Heaven (Ailanthus altissima L.). BioMed Cent. Ecol. 2:1. doi: 10.1186/1472-6785-2-1

Tsuzuki, E., Yamamoto, Y., and Shimizu, T. (1987). Fatty acids in buckwheat are growth inhibitors. Ann. Bot. 60, 69-70. doi: 10.1093/oxfordjournals.aob. a087423

Turk, M. A., and Tawaha, A. M. (2003). Allelopathic effect of black mustard (Brassica nigra L.) on germination and growth of wild oat (Avena fatua L.). Crop Prot. 22, 673-677. doi: 10.1016/S0261-2194(02)00241-7

Wardle, D. A., Nicholson, K. S., and Rahman, A. (1993). Influence of plant age on the allelopathic potential of nodding thistle (Carduus nutans L.) against pasture grasses and legumes. Weed Res. 16, 223-227. doi: 10.1111/j.1365-3180.1993. tb01919.x

Weidenhamer, J. (1996). Distinguishing resource competition and chemical interference: overcoming the methodological impasse. Agron. J. 88, 866-875. doi: 10.2134/agronj1996.00021962003600060005x

Wesson, G., and Wareing, P. F. (1967). Light requirements of buried seed. Nature 213, 600-601. doi: 10.1038/213600a0

Weston, L. A. (1996). Utilization of allelopathy for weed management in agroecosystems. Agron. J. 88, 860-866. doi: 10.2134/agronj1996. $00021962003600060004 \mathrm{x}$

Weston, L. A. (2005). History and current trends in the use of allelopathy for weed management. HortTechnology 15, 529-534.

Weston, L. A., Harmon, R., and Mueller, S. (1989). Allelopathic potential of sorghum-sudangrass hybrid (sudex). J. Chem. Ecol. 15, 1855-1865. doi: 10.1007/ BF01012272

Wyman-Simpson, C. L., Waller, G. R., Jurzysta, M., McPherson, J. K., and Young, C. C. (1991). Biological activity and chemical isolation of root saponins of six cultivars of alfalfa (Medicago sativa L.). Plant Soil 135, 83-94. doi: 10.1007/ BF00014781

Yang, P., and Kinghorn, D. (1985). Coumarin constituents of the Chinese tallow tree (Sapium sebiferum). J. Nat. Prod. 48, 486-488. doi: 10.1021/np5003 $9 \mathrm{a} 025$

Yatagai, M., Ohira, T., and Nakashima, K. (1998). Composition, miticidal activity and growth regulation effect on radish seeds of extracts from Melaleuca species. Biochem. Syst. Ecol. 26, 713-722. doi: 10.1016/S0305-1978(98) 00034-9

Conflict of Interest Statement: The authors declare that the research was conducted in the absence of any commercial or financial relationships that could be construed as a potential conflict of interest.

Copyright (C) 2018 Saha, Marble and Pearson. This is an open-access article distributed under the terms of the Creative Commons Attribution License (CC BY). The use, distribution or reproduction in other forums is permitted, provided the original author(s) and the copyright owner are credited and that the original publication in this journal is cited, in accordance with accepted academic practice. No use, distribution or reproduction is permitted which does not comply with these terms. 